\title{
In peace and war: birth control and population policies in Norway (1930-1945)
}

\author{
Astri Andresen* and Kari Tove Elvbakken \\ University of Bergen \\ *Corresponding author. Email: astri.andresen@uib.no
}

\begin{abstract}
While Norway in the 1930s had relatively liberal policies with regard to access to contraceptives, and an increasing number of legal abortions were carried out, the regime that was installed after occupation in 1940 reined them in, fuelled not only by Nazi ideology but by what new the regime saw as a most threatening population decrease. With reference to population policies in other West-European countries, this article compares Norwegian population policies under occupation with that of the 1930s, discusses if the policy towards all groups were the same, and the extent to which the new policies contributed to increasing birth rates in occupied Norway.
\end{abstract}

The regime that was installed in Norway after the German occupation in spring 1940 gave high priority to the introduction of population policies that resembled those that had been implemented in Germany after Hitler's takeover. ${ }^{1}$ Pronatalist welfare measures were launched, birth control clinics were closed and more restrictive legislation on access to contraceptive means and abortions was passed. The Norwegian 1934 Act on Sterilisation was revised so that sterilisation on demand was no longer an option. ${ }^{2}$ In this article, we discuss the extent to which new policies, rules and regulations differed from those of the pre-war period and the effectiveness of the new pronatalism in influencing birth rates. Birth rates rose sharply between 1941 and 1942 (see below) when the first of the new measures was put in place and remained high during the war - but can the rise be ascribed to wartime politics? It is impossible to establish cause and effect in a case like this, but in this article, we argue that National Socialist (NS) rule restricted access to abortions and relatively safe contraceptive means to such an extent that the risk of pregnancies and births had to increase. The standard explanation offered for rising birth rates in Norway in this period - the share of young and fertile people in the population - should be supplemented by wartime population policies. ${ }^{3}$ To argue the case, we explore birth control policies and practices during the war and in the pre-war 1930s.

Recent work on the baby boom has moved its onset from post-war to the late 1930s and in some cases to the war years, ${ }^{4}$ and this temporal shift has provoked new interest in interwar fertility. While demographers Van Bavel and Reher called for new research 
into non-demographic factors, such as culture and pronatalist policies, ${ }^{5}$ and historian Kline demonstrated how one factor - 'positive' eugenics - worked to install a new and birth-friendly mentality in the United States, ${ }^{6}$ demographer Sanchez-Barricarte argued that the shift called for economic explanations of marital fertility that correlate economic crisis and childbearing; a reduced GDP per capita and less public welfare encouraged couples to once again, as before the demographic transition, seek future security in their children. Sanchez-Barricarte dismissed the rise in birth rates having anything to do with restricted access to contraceptives; if people wanted to avoid pregnancies, they could have resorted to traditional means. ${ }^{7}$

To change practises and obtain the desired results might in this field not have been that easily done, however, and it should also be noted that regulated access to contraceptives combined with monetary support to families with many children was institutionalised in several European countries in the 1930s. ${ }^{8}$ D. V. Glass' survey of the status of abortion legislation in Belgium, Germany, France and the three Scandinavian countries (Norway, Sweden and Denmark) in 1938, ${ }^{9}$ furthermore showed that the first three had introduced more restrictive abortion legislation, but that it was not necessarily strictly enforced. ${ }^{10}$ In France, this leniency was one of the reasons for the new Code de la Famille in 1939. At the other end of the scale, Glass concluded that the Scandinavian countries were likely to pass legislation that would allow abortion on medical, eugenic, humane (if the pregnancy was a result of rape or incest) and social grounds. All three countries had social-democratic (minority) governments, and legislative committees had recommended such legislation. However, the parliaments in Denmark and Sweden legalised abortions but not on social grounds.

The Norwegian government did not present any abortion legislation to the parliament before the war, and this allowed for a relatively liberal practice - compared to the early 1900s - to continue. The strictest anti-abortion and anti-contraceptives acts and the broadest pronatalist measures thus only arrived in Norway with the war, making the country in this respect somewhat different from the larger and more influential European states both in the 1930s and during World War II (WWII).

In this paper, we first discuss our sources and show how the politicoadministrative apparatus in Norway was transformed after the German occupation. Among the changes was the establishment of a new body, the Population Office. After the deportation of Norwegian Jews in October and November 1942, the Office dealt with issues of 'race." ${ }^{11}$ In section 3, we therefore discuss if the Population Office introduced specific means that targeted the indigenous Sami and the Romani people. The first is an ethnic, the second a national minority, and both German and Norwegian NS propaganda represented them as inferior groups. This discussion is followed by sections on the fertility decline in the 1920s and 1930s, the use of contraceptives and abortions to attain it, and the role of the new birth control clinics. The last part of the article is devoted first to occupation and the various means the regime established to increase birth rates, and second to a discussion of how the new policies might have influenced the rates.

\section{Sources}

Our main sources from the war years were produced by the Population Office (Befolkningskontoret) which was under the Ministry of Interior's Health 
Department (Helseavdelingen, hereafter Health Department). The Population Office was a new creation, and one of the eight offices in the Health Department. ${ }^{12}$ The Population Office's archive, kept at the National Archive of Norway (Riksarkivet), deals with population policies broadly defined, but particularly with efforts to stimulate births and discourage birth control by regulating access to modern contraceptives and prohibiting abortions and the means to perform them. Thus, the archival collection also deals with the closure and liquidation of birth control clinics (mødrehygienekontor) in 1941. The clinics were mostly established and run by the radical labour women's movement. Anders Gogstad used Population Office material in a general study of health and health policies under occupation, but access to birth control was not a topic he investigated. ${ }^{13}$

Documents from the archive of Ministry of Justice at the National Archive have provided information on questions pertaining to legislation on abortion in the 1930s and during the occupation. The material has previously been used in studies of legal aspects of abortions and sterilisation. ${ }^{14}$ The Norwegian Labour Movement's Archive and Library (Arbeiderbevegelsens arkiv, Arbark) also holds material of interest to the study of the abortion issue before WWII, some of which have previously been utilised for similar reasons.

Sources produced by some of the birth control clinics have been investigated. The Bergen clinic's material is kept at the Bergen City Archive (Bergen byarkiv); material from the Tromsø clinic is deposited at the regional state archive in the city of Tromsø. The material has not been utilised for research, in contrast to sources produced by the clinic in Oslo, which was also the largest. ${ }^{15}$ The archives of the birth control clinics are far from complete for several reasons. The clinics destroyed their index cards and other material soon after the occupation to prevent it from falling into German hands. In addition, owing to the German army's scorched-earth policy when they had to retreat from the northernmost part of the country, Finnmark, to our knowledge, no remaining archival material from the county's first birth control clinics exists. Source material not only from the Population Office but also from war trials against leading Nazis has been useful to provide a clearer picture of what happened to birth control and the birth control clinics after their closure.

Demographic change over the decade 1935-1945 is presented using statistics and statistical analysis produced by Statistics Norway. ${ }^{16}$ Literature on the fertility decline has also been of help, as we discuss below.

\section{From the fringes of power to the Ministries}

Before WWII, the Norwegian NS Party was a party without power. Established in 1933, it participated in the last two parliamentary elections before the war (1933 and 1936) but was not represented in the Norwegian parliament. ${ }^{17}$ It had some success in a few municipal elections, and in 1940 the NS made its way to power after the Norwegian government failed in its attempt to stop the German army. The government fled to England, established itself in exile and declared Norway a part of the front against Hitler. After unsuccessful German efforts to create a German-friendly government recognised by the sitting parliament, the occupiers appointed new ministers (Kommissarer) in September 1940. Most of them were 
Norwegian Nazi party members. From 1940 to 1942, the ministers were not allowed to meet or act as a government, which meant that each minister was responsible for policy in their field of administration. However, each minister and, from February 1942, the government that Vidkun Quisling was eventually allowed to form were under the control of the German Reichskommissar Josef Terboven. ${ }^{18}$ He had the Gestapo, the German state police, at his command. All legislation made by the ministries had to be approved by the German Reichkommissariat before being enacted.

The NS population policy was placed under the Ministry of the Interior and its Health Department. The Ministry of Justice commented on all proposals for new legislation, including proposals from the NS Health Department for new health and population legislation, but from autumn 1940, the NS party was able to influence Norwegian population policies. New legislation also had to be approved by the occupying power, the Reichkommissariat. The Health Department was created through a merger of the Directorate of Health (that had been outside the Ministry of Social Affairs) and the Department for Health (within the Ministry of Social Affairs) ${ }^{19}$ It was led by the Nazi Party member and physician Thorleif Dahm Østrem. The connection to the new and stronger Ministry of Interior is a sign of the increased importance of health and population issues, as is the establishment of the Population Office.

Despite the occupation, many top Norwegian bureaucrats remained in their former positions, and to some extent, they were able to influence, or at least delay, decisions. For that reason, but also for others, the theory of the occupation causing a profound shift in all fields no longer prevails. Pertaining directly to our topic, the historian Øystein Sørensen has claimed that there were continuities in welfare policies from the 1930s through the war years and into the $1950 \mathrm{~s}^{20}$ The Norwegian economy has been described in terms of continuity from 1935 onwards and throughout the war. ${ }^{21} \varnothing y$ stein Giæver and others have found similarities between pre-war and wartime sterilisation acts and between a proposal for an act that would have prohibited abortions in the late 1930s and the actual 1943 Act. $^{22}$

\section{The new regime, the 'Nordic race' and the minority populations}

The Norwegian birth rate, live births per 1,000 people, was 29.69 in 1900, 26.31 in 1920 and 14.3 by 1935 . In 1936, the downward trend was halted, and the rate reached 16.13 in $1940 .{ }^{23}$ Statistician Julie Backer at Statistics Norway found that the size of the reproductive population was the main factor behind variations in birth rates until 1900. After 1900, however, a new factor had arisen that 'for years to come was decisive for changing birth rates, voluntary birth control' (authors' translation). ${ }^{24}$

Both the decreasing birth rates and the 'new factor' were reasons for the establishment of the Population Office in 1941. It started its work in September of that year under the leadership of Sverre Kvassnes, ${ }^{25}$ and its main aim was to counteract the use of contraception and abortions, stimulate births by pronatalist measures and establish a system for mother-and-child health clinics for infants and young children. The office also took an interest in the health of schoolchildren and made a survey among city health authorities to obtain an overview of available summer camps. The first head of the office described the goal of the new population 
policies in one sentence: 'to strengthen our people quantitatively and qualitatively contrary to what has previously been done'. ${ }^{26}$ The consequences of birth control 'population loss' - was described as a tragedy with reference to theories common in Nazi ideology, including the value of 'the Nordic race':

The Norwegian population is from the hand of nature no doubt one of the best equipped peoples. There is in reality no country with a better (emphasis in original) equipped population. It should therefore be a matter of course that Norway, instead of being a country in the lead on birth control, exceeded other countries with a strong population increase (authors' translation). ${ }^{27}$

The 'Nordic race' ideology created a difference between German policies in some occupied countries in Eastern Europe and Norway, as Nazi ideology held the first had populations of less value than the 'Aryan' or 'Nordic' race. ${ }^{28}$ After the deportation of Jews in 1942, the Population Office became responsible for issues of 'racial biology', which to some extent included policies toward the indigenous Sami and the Romani people. Because the NS shared Nazi racial ideology, it is likely that population policies toward the two groups differed from the general policies, and the historian Kåre Olsen has claimed that German policies aimed at increasing birth rates in Northern Norway. ${ }^{29}$ He provided no evidence, however, that such a policy was ever put in place. Documents in which the Population Office urged local communities in Finnmark to intensify efforts to establish mother-and-child health clinics to 'serve the new population politic' (see below) to some extent contradicts the claim. ${ }^{30}$ As we will later show, the evidence is lacking that policy towards the Sami in the fields of sterilisation and abortion departed from the general policy, while it might have diverged in cases that involved the Romani.

In October 1943, the leader of the Population Office wrote that the Health Office was working on a statement on the 'Lapp question' (lappespørsmålet). It was obviously more complicated than the 'Jew- and Gipsy-problem', that was said to require legal provisions prohibiting intermarriage. ${ }^{31}$ We have found no such statement, possibly because some material has been removed from the archives, but the Norwegian branch of the German Lebenborn organisation, whose mission it was to further the birth and raising of 'racially' valuable children with Norwegian mothers and German fathers, had already ruled out supporting Sami applicants on grounds they did not belong in the right 'racial' group. ${ }^{32}$

'Racial mixture' was a recurring topic. Notably, a book called Slekt og individ (Race and Individuals) published in 1941 and accepted for use in school, co-authored by the first head of the Population Office, Kvassnes, only mentioned the Sami as one of the 'small races' of Europe with no further comments. ${ }^{33}$ It condemned 'racial mixture' in general, as was common in Nazi and eugenic ideology, without referring to the Sami, but in a letter Østrem, the Director General of Health, discussed the 'problem' of 'racial mixture' between Norwegian and Sami individuals: the Sami would disappear as a distinct racial group (gå under) if they continued marrying Norwegian partners reindeer herding would end, and the nomadic culture would disappear. 'Tribally-conscious Lapps' (stammebevisste samer) realised this, he felt, and 'seek to hinder racial mixing' (authors' translation). ${ }^{34}$ The exclusion of pregnant Sami women from the Lebensborn program 
could thus be seen as a measure to keep not only the Nordic, but also the Sami 'race' 'clean'. The message was in any case ambiguous: 'The Lapp question is by us regarded as equally important as the Jew-problem. ${ }^{35}$ Considering the fate of the Jews, to receive that level of 'importance' was not promising, but according to the director of the Health Department, measures that could 'lift the self-respect of the Sami and thereby prevent their cultural and racial collapse' were also considered. $^{36}$ Among them was the improvement of elementary schooling for Sami children in Finnmark.

Despite Nazi-regime ambivalence, it is reasonable to conclude that a population policy that explicitly targeted the Sami was absent in Norway; they were included in the overall policies. Lebensborn's condemnation of 'racial mixture' in principle kept Sami women and their children out of the Lebensborn program, but this hardly affected birth rates, and it was part of a racial program, not a population program. The absence of specific policies had reasons that went beyond both ideological issues of 'race' and population. Though the Norwegian Nazi Party held a negative attitude to the Sami as an 'inferior race', the German attitude was more complicated, balancing race theories on the one hand and more romantic and touristy approaches on the other. ${ }^{37}$ The 'romanticising' was seemingly common enough for the Population Office to worry that the German attitude was much too positive and that German newspapers as a consequence did not sufficiently appreciate the 'German abilities and qualities like resourcefulness, courage and faith, persistence, and patience' among the Norwegians in Northern Norway. ${ }^{38}$ More important, however, was that the Sami, according to the head of the Gestapo, Heinrich Himmler, constituted no danger to 'the pure Aryan race', and most importantly that they, owing to their knowledge about living in the Arctic, could be very useful to the Germans in their war against the Soviet Union. ${ }^{39}$ With no need for specific Sami population policies that went beyond condemnation of 'racial mixture', it was the population decrease in Norway that called for action.

\section{The fertility decline in Norway in the 1920 s and 1930 s}

Measures to reduce infant mortality and safeguard children born out of wedlock had been introduced in the early years of the century but other measures to increase the population had not been prioritised by the Norwegian government in the 1930s. The country had, for example, not appointed a population commission in the 1930s, as had the UK, Sweden and Denmark. ${ }^{40}$ That is not to say population issues were not discussed, both outside and within the labour movement. ${ }^{41}$ Among conservative politicians, and some of the eugenically inspired radicals, there was a fear that declining population quality would follow in the wake of middle-class birth control. $^{42}$

As mentioned, Backer saw voluntary birth control as a factor explaining the fertility decline in the first part of the twentieth century, but she did not discuss how this new practice was effected. The standard work on fertility decline in Norway during the period 1890-1930, Fra stua full til tobarnskull (1984) by historians Sølvi Sogner, Hege Brit Randsborg and Eli Fure, provides an analysis of the process. ${ }^{43}$ Utilising cultural and economic variables and analysing developments at both the municipal and national levels, the authors showed that birth rates in 
Norway decreased earlier in towns and densely populated areas than in the countryside. The decline came first and was strongest where secondary and tertiary industry dominated and was slower and came later elsewhere, and it was particularly slow in areas dominated by fisheries. In reindeer herding communities in the northernmost county, Finnmark, there was no decline. The authors concluded that the change in attitudes to birth control happened in parallel with a restructuring and modernisation of the economy. They did, however, find cultural factors of importance; areas dominated by what in Norway is known as counterculture (temperance movements, lay-religion and a movement to further the 'new Norwegian' language (nynorsk)) were latecomers, while areas where women used their vote were forerunners. Forerunners were mainly towns and industrialised areas.

\section{Access to contraceptive means and abortions in the late 1920s and 1930s}

Sogner argued that Norway's fertility decline was achieved through traditional means'. She held that withdrawal continued to be 'the most popular [contraceptive] method well into the twentieth century.' ${ }^{44}$ 'Well into the twentieth century' is an ambiguous phrase, but we understand Sogner to mean at least until $1930{ }^{45}$ Historians Fisher and Szreter for their part argued that the British working class preferred withdrawal as a method of contraception well into the post-war period and into the 1950s. ${ }^{46}$

In arguing that traditional means dominated, Sogner consulted three main sources. The first was a report that covers the first 25 years of the Oslo birth control clinic (1924-1949). In that period, ' 49 per cent of their women clients had used withdrawal as their main method prior to a visit to the clinic to have a pessary adjusted'. However, this suggests that more than half of the women visiting the birth control clinic prior to this, as a rule or from time to time, had used modern contraceptives along with abstinence and safe periods. After the visit, the percentage rose, because providing contraceptive means was the clinic's main raison d'être and at the heart of its practice. The second of Sogner's sources was a survey conducted in 1973-1974 on methods in 1955 which showed that ' 43 per cent of the respondents were still using withdrawal'. Among the remaining 57 per cent, we may assume that some had turned to modern contraceptives. The third source is a survey by Statistics Norway in 1977 which 'confirmed that withdrawal was the method of choice until the late 1950s' ${ }^{47}$

We do not doubt the continued use of traditional methods. However, we suggest that the sources used by Sogner indicate that modern means were competing with traditional methods even if they had not replaced them, and not only among the upper classes who supposedly were the first to modernise birth control but also among working-class women. This was not least due to the birth control clinics that had been established from 1924.

\section{The birth control clinics}

The birth control clinics had been established by feminist activists and the labour women's movement, a movement containing different organisations under changing names, starting in 1924 and continuing through the 1930s. At the outbreak 
of WWII, there were 13 birth control clinics spread over the country, with the most limited presence in the southwest - the stronghold of traditional cultural resistance and in the north. The clinics were inspired by British and German clinics and offered information that was not generally available even from doctors. Although popular medical books soon appeared that targeted the working classes, for example, Vår helse (Our health), together with a popular journal by socialist doctors for sex education (Populort tidsskrift for seksuell opplysning), the clinics were important for informing working-class women about birth control and providing them with contraceptive means for free or, if they could afford it, for purchase. ${ }^{48}$

Diaphragms were preferred by the clinics and others who informed about birth control; they were the only contraceptive means women controlled, they were inexpensive and they could be used many times. Var helse informed in detail how they should be washed and how often and how long they could be kept inside. ${ }^{49} \mathrm{~A}$ drawback was that, ideally, diaphragms had to be fitted by a doctor at the birth control clinics, but there were other ways of having them fitted. A well-known example from Scandinavia showing that a medical education was no prerequisite is the birth control activist, syndicalist and journalist Elise Ottesen Jensen, who in the 1930s travelled around Sweden fitting diaphragms. ${ }^{50}$ According to the Swedish historian of ideas, Lena Lennerhed, physicians could not be expected to master the task and the situation was most likely the same in Norway. ${ }^{51}$ Nurses were more accessible than doctors, who in the interwar years often worked at the birth control clinics without any salary and devoted less time to the clinic than the paid nurses and midwives. ${ }^{52}$ Physicians and nurses from the Oslo clinic travelled around Norway arranging meetings and imparting information. Medical students attended training at the clinic and young physicians were employed in districts all over the country, contributing to the spread of new methods of birth control.

The clinic in Oslo was well attended; in 1932 and 1933, it had 7,000 to 8,000 visits a year, with some women visiting more than once. Most of the visitors saw a nurse and around 1,000 per year saw a doctor. ${ }^{53}$ In 1936, there were more than 2,000 visits to the doctor, ca. 13,000 to the nurse. ${ }^{54}$ Not everybody sought the clinic for birth control. Some came for medical check-ups during pregnancy, and the clinic also provided health care for children. ${ }^{55}$ Even so, for a relatively small city like Oslo (253,127 inhabitants in 1930), the number of visitations were high, indicating that many women found the services of the clinic useful. The Oslo birth rate was already very low in 1930 (9.4 live births per 1,000, compared to 17.0 for the entire country), ${ }^{56}$ a decrease of 68.2 per cent from 1920. The two other relatively large cities in the country, Bergen and Trondheim, also experienced a reduction in the birth rate, but not equally strong (56.4 per cent and 56.2 per cent, respectively). ${ }^{57}$ The difference surely had several explanations, but we note that, in contrast to Oslo, the two smaller cities had no birth control clinics until after 1930.

The birth control clinics did not, however, reach out only to women who lived in their vicinity. Though the Penal Code prohibited advertisements for contraceptive means until the 1970s, from the mid-1920s information about contraceptives were regularly presented in working women's journals, and both before and after that, they were offered for sale from various agencies. ${ }^{58}$ The Labour Women's Journal (Arbeiderkvinnen), for example, printed advertisements for the Oslo office in every issue from the clinic's opening in 1924 onwards, together with advertisements 
for the sale of contraceptives. ${ }^{59}$ The Labour Party's press also wrote regularly about the clinic and the largest newspaper in Northern Norway, Nordlys, advertised for free the services of the Tromsø clinic. ${ }^{60}$

In the 1930s, the prohibition against advertisements was not at all adhered to. Thus, Norway resembled France and Belgium during this period. D. V. Glass claimed that, in those countries, similar acts were 'more effective in theory than in practice'. ${ }^{61}$ The French Code de la Famille (1939) stated that it was forbidden to practice birth control with technical means, and the intention was clearly to limit access by stricter control measures. ${ }^{62}$ By contrast, the organisation for social security in Norway (Rikstrygdeverket) agreed to allow support for the birth control clinics from 1932, ${ }^{63}$ and from 1938, the parliament gave economic support to the establishment of birth control clinics. The support grew more pronounced after the Labour Party government had appointed the young socialist physician Karl Evang as Director General of Health. He was a well-known sex educationist and activist for birth control and legal abortions. ${ }^{64}$

The larger urban municipalities also supported their local birth control clinics, and the overall picture is that birth control, including abortions, had broad support in social-democratic and communist circles, and at times from members of other parties. ${ }^{65}$ Labour Party members argued that to limit the number of children was one of the ways the working classes could strengthen its position, and that to the working classes, the size of the population was not important in the short run. ${ }^{66}$ In the long run it was, but to avoid population decrease, a new social policy - if not socialism - was needed. ${ }^{67}$ Regulating access to contraceptives and abortions was not the right answer to decrease. The political influence both at the local and the national level of the political left was crucial in gaining support for birth control clinics and for a relatively liberal stance in the abortion issue. It could also be that the declining population was not felt as equally threatening in Norway, which had been neutral in the First World War, as in countries that had lost huge numbers of soldiers. Norway's official policy in the late 1930s was still to remain neutral, not least due to the pacifist traditions of the Labour Party. ${ }^{68}$

Even so, it must be emphasised that influential political groups and voluntary organisations, including some women's groups, strongly opposed the use of contraceptive means in Norway for moral reasons but also for fear of depopulation. ${ }^{69}$ Racialised arguments were not uncommon. 'It will be the end of the white race if birth control continues' (authors' translation) a local newspaper in Bergen quoted the senior registrar at the local maternity hospital in a debate over the establishment of a local birth control clinic. ${ }^{70}$

In 1932-1933, the Oslo clinic received almost 2,000 letters from women all over the country, and written requests had increased since the opening of the clinic: from 1924 until 1929, the clinic received 4,300 letters compared to more than 1,000 a year in the early 1930s. In one year, 1934, the clinic answered 1,617 letters; in 1935, it answered 1,714; and in 1936, it answered $1,748 .^{71}$ The clinic's employees might have referred women to local doctors or perhaps nurses for a diaphragm as there was cooperation between the Oslo clinic and local doctors and midwives. ${ }^{72}$ The Union of Socialist Physicians (Socialistiske legers forening), which had members all over the country, was supportive of the birth control clinics and sex 
education was one of its priority issues. Some of its members were district physicians willing to assist women in need of contraceptives or an abortion. ${ }^{73}$

Among the visitors to the clinics were many asking for help to terminate a pregnancy. Section 245 of the 1902 Penal Code banned abortion unless the woman's health or life was in danger, leaving the doctor to decide who fitted the description. The law seems to have been increasingly liberally practiced in the early $1930 \mathrm{~s}^{74} \mathrm{~A}$ penal committee formed in 1934 to draft abortion legislation (Straffelovkomiteen) claimed that abortion 'had become more acceptable as it became more common' (authors' translation). ${ }^{75}$ There is no evidence that the clinics informed visitors on illegal abortionists, but the number of illegal abortions was high. The Penal Code Committee estimated them (abortions 'by quacks') to account for nearly half $\left(2,260\right.$ of 5,425) of all induced abortions in $1933 .^{76}$ The Committee held, however, that more widespread use of contraceptives was about to reduce the need for abortions.

Abortion was a high-conflict political issue from the early 1930s. The Scandinavian governments appointed commissions in the first half of the 1930s to make proposals for abortion legislation. In Norway, massive reactions occurred to the appointment of the Norwegian penal committee in 1934, gathering 230,000 signatures, headed by conservative parties and women's organisations, the church and Christian organisations, even before its legislative proposal was given to the government in 1935. The penal committee proposed an abortion act that allowed for abortion on social grounds. The protesting organisations and their supporters argued for legislation that could stop what they saw as a far too liberal practice. On the other side, radical feminists and women's labour organisations mobilised and supported the liberal proposal. ${ }^{77}$ An alternative proposal following a restrictive line was presented to the parliament by members of the opposition and sent to the government in $1939 .{ }^{78}$ The Norwegian Labour Party government did not have sufficient votes in Parliament to pass the liberal act and it feared the conservative one would be passed if the question was raised. It thus refused to present any of the proposals, reasoning that no act was better than a restrictive one which would put an end to the relatively liberal interpretation of section 245 of the Penal Code of what constituted threats against women's life and health.

The number of legal abortions in Norway was already higher than in neighbouring countries in the 1930s. In 1932, 1,622 legal abortions were reported. The country's population was 2.8 million, which, in 1930, was only half the size of the Swedish and 750,000 less than the Danish populations. Sweden reported 108 legal abortions in 1932 and Denmark 300 in the same year, thus, the political situation in Norway seems to have allowed for a more liberal abortion practice than Denmark and Sweden. ${ }^{79}$ This continued after abortion legislation that did not allow for abortion on social grounds was passed in Denmark in 1937 and Sweden in 1938.

From the beginning, the Oslo office had set itself a goal to help establish clinics elsewhere. The next offices to open were in Stavanger (1928), Drammen (1929) and Trondheim (1935). In Bergen, the second largest town after the capital, an office was established in 1936. Several offices opened in northern Norway in the 1930s (Bodø, Narvik, Harstad, Tromsø and Berlevåg), in a huge region with relatively 
few doctors. The clinics were established as private enterprises, as they sold contraceptives and were economically dependent on the income from their sale.

In 1936, socialist and working-class women founded the National Organisation for Birth Control Clinics (Landsforeningen for mødrehygiene). ${ }^{80}$ Information about how many women the birth control clinics outside the capital helped is scattered, but the National Organisation reported that 8 of the 12 clinics had been visited by a total of 5,000 women in 1937, many of them several times. ${ }^{81}$ The remaining four did not report numbers of visits. The board at the Troms $\emptyset$ clinic also did not release any numbers, but in 1938 it mentioned that the National Organisation was satisfied with its good work. ${ }^{82}$ In 1940, the Tromsø clinic was said to have been well attended, and during its short existence it had to expand. ${ }^{83}$ The clinic in Odda, a small industrial town in Western Norway supported by both working and bourgeois women, soon attained a strong position. ${ }^{84}$ In Skien, a small town southwest of Oslo, a birth control clinic opened in 1931. The medical doctor and socialist activist Nic Hoel reported from the clinic after only a few months that it had many visitors, more than 500, and that the need for information and for contraceptives was enormous. ${ }^{85}$ In the county of Østfold, southeast of Oslo, an ambulatory clinic was established in 1934, reportedly to meet the needs of women in several smaller industrial cities in the area. ${ }^{86}$ Data from the Bergen clinic, however, show that, despite being the second largest town in Norway, its clinic helped only 134 women with contraception in $1939 .{ }^{87}$ Why the numbers were low is difficult to explain, but at this clinic, women had to justify the need for contraceptive means, and this might have made it easier for them to use mail order instead of visiting the clinic. ${ }^{88}$ The office was established by a coalition of women's organisations, not only radical women, and this might also have influenced the number of visitors.

\section{Occupation, pronatalism and new regulations}

By 1940, direct access to birth control clinics was obviously uneven, but many women were helped through corresponding with the Oslo office or one of the other clinics. $^{89}$ In Germany, after the 1933 Nazi takeover of the government, birth control clinics were forbidden and pronatalist policies were implemented. Doctors who had been working at the clinics were imprisoned. ${ }^{90}$ In Norway, in late April 1941, the new authorities closed the birth control clinics. ${ }^{91}$ The announcement of the closure was made in a radio speech on 26 April 1941 by Borghild Skar, NS member, consultant at the Population Office and responsible for organizing the liquidation of the clinics after their closure. ${ }^{92}$ The clinics' belongings, including their stock of contraceptives, were confiscated. The birth control clinics had been corporations, and liquidation of their assets started in September the same year. Contraceptives were handed over to the German authorities and other equipment, such as baby clothes and scales, was given to the NS Women's Organisation (Nasjonal Samlings Kvinneorganisasjon, NSK).

The closures did not come as a surprise. What had happened to access to birth control and abortions and, in general, the racial policies in Germany were well known among radicals in Norway. Consequently, after the occupation, the clinics had prepared for difficulties by destroying archival material, particularly material that 
contained information on individual women. This turned out to be a wise decision as Nazi authorities were very interested not only in those who had worked at the clinics but also who had visited them. ${ }^{93}$ The Trondheim clinic, in particular, was suspected of having been 'a notorious abortion institution' (eine notorische Abortanstalt). ${ }^{94}$ The Nazi authorities tried to document this claim by developing statistics from the meagre information they managed to collect from preserved index cards that showed that more than 25 per cent of the women visiting the birth control clinic over four years had had an abortion. ${ }^{95}$ The Oslo birth control clinic arrived at a similar conclusion in $1937 .^{96}$

\section{Pronatalism and racial improvement}

As the birth control clinics had also provided health care for babies and small children, closing the offices might have affected children's health. Mother-and-child health clinics, called 'Mother and Child stations', were, however, at the heart of the pronatalist policies instigated by the Nazi government in collaboration with the Reichskommissariat (rikskommisariatet). Unlike the birth control clinics, prewar child health clinics that had not been involved in or associated with birth control could continue their work, and in July 1941, the Ministry of Interior got legislation approved by the Reichkommissarat that instructed all municipalities to establish and run mother-and-child health clinics.

By February 1943, 53 new clinics had been established, resulting in 282 clinics throughout the country, organised under the Health Department. ${ }^{97}$ The NS Women's Organisation engaged in the work, in some cases with equipment obtained via the liquidation of the birth control clinics. Of the former actors within this field, the Population Office eventually decided that only one voluntary organisation, the Norwegian Women's Health Organisation (Norske kvinners sanitetsforening, NKS), was sufficiently ideologically sound to be allowed to continue its important work. NKS seemed to 'have a clean shield' (ha rent skjold). Their work was 'built upon healthy principles, and it can be fully recognized'. ${ }^{98}$ The healthy principles included a negative attitude both to contraceptive means and abortions. The Office instructed the leader of NKS to keep outside its ranks anyone who had been engaged in 'propaganda for abortion' or was involved with the birth control clinics. ${ }^{99}$ The child health clinics needed ideologically sound leaders, physicians and nurses:

When establishing new stations, it must be ensured that the leader and the personnel earlier have not been involved in the destructive population policy that lately was so modern in this country. Ideologically, they must support our population policy, to contribute to an improvement of our population qualitatively as well as quantitatively. The Population Office is therefore sceptically tuned towards persons who have earlier been members of one of the political parties that have contributed to the situation today, and it prefers fairly apolitical persons or preferably members of N.S., [the National Socialist Party] if at the same time they are qualified (authors' translation). ${ }^{100}$

The Population Office announced to local mayors and others that neither physicians, nurses nor midwives who had been involved in the birth control clinics were to be involved in the new initiative. ${ }^{101}$ To ensure that the right persons 
were engaged, Borghild Skar from the Population Office acted as travelling secretary (reisesekretor). ${ }^{102}$ This control could be implemented with help from the NS Health Organisation (Nasjonal Samlings Helselaug), NSH, which organised all health professionals who were members of NS. Its leader had instructed the members to report on the political leanings of their colleagues, compiling a political register of Norwegian doctors. The register was shared with the Health Department ${ }^{103}$ and eventually with the Population Office that had itself produced a list of wanted and unwanted physicians. Wanted physicians were those with NS membership. ${ }^{104}$ The Population Office also received information about physicians and others who were not ideologically in favour of the new pronatalism. ${ }^{105}$ Anders Chr. Gogstad claimed almost all physicians were registered by $1942-1943 .{ }^{106}$

Expanding the network of mother-and-child clinics was not the only pronatalist effort. A policy of family allowances was instituted, defined as D. V. Glass did in 1940; a 'cash grant, quite separate from and in addition to a man's wage or salary, given to help cover the costs of raising a family'. ${ }^{107}$ Glass found France and Belgium to be prime examples of this kind of monetary support, but added that, in the two countries, the support did not initially aim at promoting population growth. ${ }^{108}$ However, the family allowance scheme in Germany after the takeover of the NS government clearly did, ${ }^{109}$ as did the Norwegian scheme. The Act on Child Support to Certain Employees (Lov om barnetilskott til visse arbeidstakere) passed on 5 December 1944 after a long battle between Norwegian and German authorities. ${ }^{110}$ The family allowance was passed too late - too close to the end of the war to influence birth rates. An ordinance for government officials (statstjenestemenn), however, that introduced an annual payment of an additional 200 Norwegian Kroner (NOK), equivalent to NOK 5,000 a year today, for every child after the first two had already been passed in December 1941. The addition was quite substantial as salaries within this group varied between approximately 300 and 1,200 NOK per month. ${ }^{111}$ The Population Office also discussed a tax reform to make unmarried men pay an extra tax (ungkarsskatten), but it was not put into effect. ${ }^{112}$

\section{The 1941 Act on the Sale of contraceptives}

After the closure of the birth control clinics, many couples were left to rely on 'natural' means of contraception or the more expensive and less reliable condoms. Condoms were not freely available to everyone for long, however. An ordinance (forordning) was enacted in December 1941 restricting the sale of contraceptive means, after the Act was passed in the same month. ${ }^{113}$ Only pharmacists or persons with permission from the Ministry of Interior, later the Director General of Health, could produce, import or sell mechanical or chemical contraceptives. It was forbidden to advertise such means, and 'chemical means, diaphragms, bougies, and instruments for vaginal syringes with tubes suited to insert into the uterus' were not to be sold to consumers who had not obtained a requisition from a doctor. ${ }^{114}$ The authorities feared that some of these means would be used to conduct abortions. The prohibitions resembled those stated in the German Police Ordinance of 21 January 1941 and in the 1939 French Family Code. ${ }^{115}$ Violators of the Norwegian ordinance were to be fined or punished with imprisonment for up to one year. The Ministry could also deprive doctors of their right to prescribe 
these means. Only physicians could legally obtain and insert diaphragms, and only in cases where pregnancy threatened the woman's life or health.

Guidelines for the implementation of the ordinance were debated in detail by the Population Office, and the Physician's Office (Legekontoret). Initially, the ordinance was proposed to forbid the import of materials that could be used to produce contraceptive means or means that could be used for abortions, similar to the German ordinance, but this was eventually deemed too difficult to enforce. The Population Office suggested that only married couples could receive prescriptions for contraceptives, but that did not pass; the German authorities emphasised that the law was not enacted for moral reasons but to stimulate population growth. ${ }^{116}$

An agreement over the guidelines seems not to have been reached until September 1943, but from the documents, we see that preliminary rules were already in place in spring of that year. The documents demonstrate that the ordinance was actively adhered to. In October 1943, for example, the Population Office gave a couple in Vesterålen (in northern Norway) permission to use condoms and a diaphragm because of the woman's poor health. ${ }^{117}$ Applicants had to explain why they needed contraceptives. An example is found in a letter from the Population Office to a pharmacy in Tromsø in July 1943: 'On the occasion of your letter of 18th last month, by means of which was ordered six dozen condoms to Troms county hospital, we kindly ask to be informed about what the condoms are to be used for' (authors' translation). ${ }^{118}$ The Population Office found the number far too high, regardless of the purpose for which they were intended.

While the ordinance restricted access to contraceptive means for men and women, as well as means used to cause abortions, female contraception could only be obtained on doctor's order. Condoms, however, 'that are also preventive' and protected against venereal disease, were easier to obtain than other means; a maximum of three condoms could be bought without a doctor's referral. ${ }^{119}$ Shipmasters, ship owners and the German army could obtain condoms in larger quantities.

The aim of the Norwegian ordinance on contraceptives was identical to the German Police Ordinance of 21 January 1941 - to stop birth control practices. Contraceptive means were comparable to 'societal poison, secret weapon depots etc.', (samfundsfarlige gifter, hemmelige våpenlagre o.l.). ${ }^{120}$ It did not become impossible to obtain contraceptives, but women, in particular, needed another reason than simply wanting to avoid pregnancy.

\section{The acts on protection of the race}

Two acts to 'protect the race' were passed during NS rule in Norway. Both acts can be placed in a longer tradition of eugenically inspired policies, both in Norway and elsewhere. ${ }^{121}$ Act no. 1 (Lov nr. 1 til vern av folkexetten) was passed in 1942 and dealt with sterilisation. ${ }^{122}$ The previous act, passed in 1934, was also inspired by eugenics. At the same time, it allowed for sterilisation on demand if the reason was 'acceptable' - the acceptable reasons were not specified. This option could be used if a family already had the desired number of children. Vår helse (above) regretted that sterilisation was mainly seen as a possibility for women as it was an operation more easily performed on men. ${ }^{123}$ The 1942 act removed the 
possibility to apply for sterilisation on "respectable grounds" and extended the range of persons that could be examined for sterilisation to include racial grounds. ${ }^{124}$ It is known that after the 1942 act, Romani persons, women in particular, were sterilised more often than others. That had also been the case under the 1934 act. $^{125}$ There are no sources indicating that sterilisation of the Sami was discussed when the 1934 act was prepared, nor is there evidence that the Sami were seen as potential targets for the 1942 act. $^{126}$ They were in this case seemingly not treated differently from others.

Eugenics was also evident in Act no. 2, which dealt with abortions, but the main intention was to reduce the numbers of abortions. The number of legal abortions in 1933 was $1,625 .{ }^{127}$ Act no. 2 was to substitute $\$ 245$ of the Penal Code which in Norway, as in continental countries, such as France (\$317) and Germany (\$218), regulated penalties for abortions. The liberal - but also eugenically inspired - proposal of 1935 was, as previously stated, not put forward. Some of the activists against this proposal were members of the Norwegian Nazi Party, and WWII thus provided them with a new opportunity to restrict abortions. Correspondence between the Ministry of the Interior and the Ministry of Justice in January 1941 shows that the Ministry of Justice was asked to comment on a draft for an abortion law that would stop the practice of abortion. ${ }^{128}$ The proposal was made by Østrem and was rather simple. His motivation was to stop the 'backsliding' (adskillig utglidning) that increased the number of abortions. Abortions were only to be allowed on medical indications, and the Director General of Health was to define what was considered a legal medical indication. The public physicians, authorised by the NS health authorities, were to decide.

The Ministry of Justice revised the proposal and returned a new draft of an abortion law in January 1942. This draft was close to the counterproposal made by Chief Physician Harald Natvig in 1938 to the 1935 proposal and put forward to the parliament - but not discussed - in 1939 by members of all parties of the opposition. Abortions were proposed to be legalised on medical, humane and eugenic indications. ${ }^{129}$ Abortion on eugenic indications was to be followed by sterilisation, and further, the proposal included a legal basis for another person to apply for an abortion on behalf of a woman, with or without her consent, if that person believed the woman was unable to take care of a child or if she was deemed unfit for motherhood. The Ministry of the Interior passed the proposal to the Reichcommisariat and Terboven for the necessary approval. Terboven had only one objection to the proposal: rape or incest, that is, humane grounds, should not be a legal indication for abortion, if the woman was otherwise healthy and of 'good racial stock'. ${ }^{130}$ To allow for abortions after rape and incest had been controversial among those arguing for a restrictive abortion law in the 1930s. The argument was that it was difficult to prove rape. With that part of the proposition removed, the 7th January 1943 Act number 2 on Protection of the Race became the first abortion legislation in Norway. Abortions could be performed on medical and eugenic indications if an application to the Directorate of Health was approved. As with sterilisation, there was no mention of Sami heritage as an indication for abortion on racial grounds.

David, Fleischhacker and Hohn claimed that the result of the German Police Ordinance of 21 January 1941 was an increase in illegal abortions. ${ }^{131}$ Grossmann 
emphasised that abortion and birth control became much more dangerous and difficult to achieve after the Nazi takeover. ${ }^{132}$ Presumably, the number of abortions decreased. Thus, what happened in Germany is unclear, and neither do the available sources about what happened in Norway provide a clear picture. We assume, however, that the risk of prosecution increased and that it became more difficult to find physicians who would perform an abortion for reasons other than those specified in the new act. Dr Kristjar Skajaa, who investigated the number of illegal abortions from the beginning of the 1900s until 1960, concluded that the number of illegal abortions increased significantly from 1941-1942 until 1945, and that many more of the illegal abortions led to hospitalisation. From 1943, there was a clear increase in deaths from abortions. ${ }^{133}$

Do we know anything about what happened regarding abortions before the 1942 Act was passed? In December 1942, the Health Department asked the county governors (fylkesmenn) to report on various health issues related to German construction work in the country, including whether there was an increase in births and abortions among unwed women. ${ }^{134}$ County medical officers ( fylkesleger) provided the county governors with the requested information based on reports from the medical officers of health in their districts (distriktsleger). They reported only about legal abortions and, in their opinion, except for two municipalities, there had been no increase. However, the County Governor in Trondheim seems to have included illegal abortions when stating that the situation was 'impenetrable' and that the pharmacies reported an increased demand for quinine that was used to bring about abortions. ${ }^{135}$

It is reasonable to read the 'no increase' answer as an indication that the situation from spring 1940 until the passing of the abortion act might have resembled the one in Germany described by Grossman: that legal abortions became more difficult to obtain. The Nazi government's anti-abortion stance, combined with the registry of physicians' political leanings, likely made left-wing and liberal doctors more careful not to overstep the boundaries of what was acceptable to the new authorities and consequently follow $\$ 245$ of the Penal Code more strictly.

The Population Office also strove to keep illegal abortions low by trying to influence verdicts passed against 'abortionists'. Østrem, for example, wrote to the Ministry of Justice complaining about 'senselessly low sentences', for example, nine months in prison for five cases of abortion. ${ }^{136}$ The Attorney General (riksadvokaten) was called upon to work for stricter punishment (skjerpet straffeutmålelse) with regard to 'crimes that concern our people's existence' (vore eller ikke voere). ${ }^{137}$ These cases demonstrate that illegal abortions took place but became an even riskier practice than before. The fact that hospitalisation due to abortion increased, as discussed by Skajaa, may indicate that the abortions were performed by untrained and unskilled persons.

The sexual policy of the new regime: pronatalist, with bans on contraceptives and abortions, might have contributed to the wartime increase in the number of children born out of wedlock. Of all children born in 1941-1945, 7.37 per cent were born out of wedlock; compared to 6.3 per cent in 1936-1940. ${ }^{138}$ According to Statistics Norway, more than one-third were children of Norwegian mothers and German (or Austrian) fathers; it was later indicated that this group of children might have accounted for around half the total. ${ }^{139}$ Some lived with their mothers, 
who received economic support from German authorities, and others were placed in orphanages run by the Lebensborn organisation. ${ }^{140}$ Both during and after the war, there was a rise in the number of children put up for adoption. ${ }^{141}$

\section{Marriages and births in Norway 1940-1945}

A sharp rise in births was seen under the occupation, steepest from 1941 to 1942, with birth rates consistently higher than interwar levels until 1945, before they once more increased in 1946. Births per 1,000 population hovered around 14.4 to 16.3 in 1935-1940, dropped to 15.31 in 1941, and then increased yearly from 1942 to 1944 , with a small decrease in $1945 .{ }^{142}$ From 1941 to 1942 , the number of live births increased from 45,773 to 53,225 ; an increase of 16.28 per cent. In 1943 and 1944, the increases were 7.6 and 8.6 per cent, respectively, while in 1945, there was a decrease of 0.69 per cent. Thus, the 14.4 per cent increase in 1946 was smaller than the 1942 increase, but it was the highest number of yearly births to date in Norway $(70,727)$. In the late 1940 s, the number of births decreased from 67,625 in 1947 to 62,410 in $1950 .^{143}$

No change took place in the average female age of marriage during the war (26.0 in 1936-1940; 25.9 in 1941-1945) ${ }^{144}$ and, thus, one explanation for higher birth rates that 'people were exposed to high risk of conception during an increased number of years' due to low age of marriage', cannot explain this development in Norway. ${ }^{145} \mathrm{~A}$ decrease happened only after 1945 . However, numbers of marriages per 1,000 rose sharply from 1931-1935 (6.53) to 1936-1940 (8.49) but decreased somewhat from 1941 to 1945 (7.91). Numbers peaked in 1946-1949 (8.99). ${ }^{146}$ Marriage rates during the war were high, but higher in the late 1930s and after 1945 than during the war.

The statistician Julie E. Backer at Statistics Norway took the changing age composition in the population into consideration as early as 1965, when she acknowledged that there was an increase in live births from 1935, with the turning point in 1942. The increase was for the largest part due to the accumulation of a greater number of younger people in the population from the early 1930s. She explained, however, that there had also been 'a certain increase in marital fertility during war'. The number of births per marriage among women marrying in 1931-1951 was markedly higher in 1942-1945 than before and after. ${ }^{147}$ She demonstrated that women who married in 1941-1945 had more children than those marrying in the years just before or after the war. In the second year of marriage, for example, women who married in 1941 had 443 children per 1,000, those marrying in 1935 had 345, those marrying in 1940 had 323, and those marrying in 1950 had $398 .{ }^{148}$ With reference to Backer's numbers, it can be argued there was a 'revival of marital fertility' in Norway in 1942-1945.

Backer did not discuss the reasons for this development. ${ }^{149}$ She had made a swiping comment, though, on the importance of birth control, though:

Around the year 1900, a new factor arrived that for years to come was to decide fluctuations in birth rates, voluntary birth control.... The general number of births was low until 1941, but in 1942 there was a notable shift. Despite the state of war in the country, it increased the following years to reach 22.6 per 1,000 in 1946 (authors' translation). ${ }^{150}$ 
Historian Guri Hjeltnes has indicated that wartime child allowances and increased rations for children - both unquestionable benefits in a time when almost everything was rationed - might have had an effect, and as we have shown, pronatalist propaganda was strengthened by economic support. ${ }^{151}$ Furthermore, Hjeltnes mentioned that information about contraception was unavailable. ${ }^{152}$ We have demonstrated that not only was information unavailable but also, to a large extent, were contraceptive means. Abortions became difficult to obtain, as did the less-used sterilisation as birth control. While traditional means could not be banned, they were less effective than diaphragms and condoms, and it must also be emphasised that with a return to traditional means, women also lost the means to independently control reproduction.

Is the return to former attitudes of children as insurance against old age, as suggested by Sanchez-Barricarte, a likely explanation for the increase in marital fertility in Norway? In 1931, Norway saw a considerable decrease in GDP, but there was a steady, albeit slow increase between 1932 and $1939 .{ }^{153}$ The Labour party government introduced a new economic policy when it gained power in 1935 and, together with international developments, it resulted in lower unemployment, better prices for agricultural products and fish and presumably better opportunities for young people to earn a living. ${ }^{154}$ The Labour party government was formed with the support of the Agrarian Party, with labour at the helm and a forest worker as prime minister, and this gave workers, fishermen and farmers new access to power - and with it, a new feeling of dignity. Combined with a 'wave of social reforms' it also gave more security. ${ }^{155}$ Thus, if economic explanations for developments in the late 1930s are to be used, it would have to be that improved economic conditions furthered childbearing - not as a consequence of a worsening economy.

In 1940-1941, GDP per capita dropped ( -9.8 per cent), while it hovered between an increase of 2.5 and minus 3.8 per cent from 1940 to 1945. Despite this, there were economic improvements for some groups and in some sectors during the war, with low unemployment and particularly good work opportunities in industry vital to the German war effort. Compared to the pre-war period, salaries in some sectors were 'fantastic' (fantasilønninger). ${ }^{156}$ As indicated by Hjeltnes, low unemployment and a rise in salaries might have influenced the desire to start a family, but this is again to explain rising birth rates with economic improvement ${ }^{157}-$ not the other way around, as suggested by Sanches-Barricarte. However, GDP did not reach the levels of the late 1930s; the situation was unstable, as was the future.

It is likely, though, that some of those in support of a greater Germany and a future Nazi Norway were ideologically inclined to heed the call for more children. Approximately 55,000 persons, young and old, women and men, were members of the Nazi Party for shorter or longer periods during the war ${ }^{158}$; not numerous enough to decisively influence the overall birth rate. Also, among the general population in Norway, birth control was opposed in the 1930s, ${ }^{159}$ and the opposition did not vanish with war. What was new with war, however, was the establishment of a restrictive population policy in a non-democratic setting.

\section{Conclusion}

The German-inspired NS population policy in Norway led to the closure and liquidation of birth control clinics and restrictions on the sale and use of 
contraceptives and of abortions. Birth control clinics and women's labour organisations had disseminated information on contraceptives among the working classes from the mid-1920s. They held birth control to be a right, and by 1940, the birth control clinics had achieved support from the Norwegian Parliament. Their position was central in providing the means for modern birth control to working women, and many must have come to rely on these means and not on traditional means like withdrawal or abstinence. With a diaphragm, women had more control than they previously had.

With many countries in Europe that would eventually be occupied by Nazi Germany, restrictive laws, such as the 1939 Code de la Famille in France, were already in place when the war started or were introduced at the eve of war. Norwegian pronatalism before WWII was not as overt as in France or Belgium, not to mention Germany; 'positive' pronatalist measures at a national level and of some magnitude were introduced only by the Norwegian Nazi government.

Abortion was an important issue before WWI, and from the early 1930s, socialists and communists, physicians and jurists in all three Scandinavian countries wanted to legalise abortion based on broad social indicators like poverty, unemployment and lack of adequate housing, but none of the countries actually did. Sweden and Denmark passed acts without any social criteria; until the war, Norway passed no act on abortion. What, from the perspective of many in the 1930 s, seemed to be the liberal practice of $\$ 245$ continued until the arrival of war.

During the occupation, the Nazi government in Norway took three particularly important steps to increase the birth rate: it closed the birth control clinics, banned information, sale and use of contraceptives and took several initiatives to stop liberal abortion practices. To these restrictive policies must be added that some of the socialist, communist and Jewish physicians had to stop practicing, emigrated, or were deported. It is reasonable to think all these changes eventually increased the chances of pregnancies, increased birth rates and added to the potential effects of pronatalism: ideological propaganda for giving birth to a child of the Nordic race and practical measures such as increased food rations and child allowances. Thus, we argue that the Nazi government introduced a population policy sufficiently effective to influence birth rates in Norway. Even if we do not know to what extent the 1942 abortion act was used, it is reasonable to argue that the passing of the law made the liberally-inclined pre-war practice far more difficult to follow.

We do not argue that the availability of well-paid jobs and, for some, the idea of a Nazi future for Norway had no effect on the wartime 'baby boom'; neither do we argue it did. We do argue, however, that the factors discussed in this article made it more difficult and less safe to regulate the number of births and that the wartime birth rates in Norway cannot be understood without taking restrictive policies into consideration. Norwegians did not necessarily want more children, but even so, limited access to relatively effective birth control and abortions made pregnancies 'happen'. Thus, the wartime baby boom and its post-war continuation must be explained differently. While the first was to some extent imposed, the second is assumed to have resulted from individual choice. Even so, pronatalist sentiments were strong after the war and reliable contraceptive means remained in short supply, with information about contraceptives contested and abortion not yet legalised. 


\section{Notes}

1 For Nazi population policies in Germany, see A. Grossmann, Reforming sex: the German movement for birth control and abortion reform, 1920-1950 (Oxford, 1997).

2 The Population Office that was established in Norway in 1941 is described by A. Ch. Gogstad, Helse og hakekors. Helsetjeneste og helse under okkupasjonsstyret i Norge 1940-1945 (Bergen, 1991). Eugenics and abortion, see $\varnothing$. Giæver, 'Eugenisk indikasjon for abort - en historisk oversikt', Tidsskrift for den norske Logeforening 24, 125 (2005), 3472-6 (74). Eugenics and sterilisation, see P. Have, Sterilisering av tatere 1934-1977. En historisk undersøkelse av lov og praksis (Oslo, 2000); G. Broberg and N. Roll Hansen, Eugenics and the welfare state. Sterilization policy in Denmark, Sweden, Norway and Finland (East Lansing, Michigan, 1996); N. Roll-Hansen, 'Some thoughts on genetics and politics. The historical misrepresentation of Scandinavian eugenics and sterilization', in H. I. Petermann, P. S. Harper and S. Doetz eds., History of human genetics (Springer, Cham, 2017).

3 J. Backer, Ekteskap, fødsler og vandringer i Norge 1985-1970 (Oslo, 1965).

4 J. Van Bavel and D. S. Reher, 'The baby boom and its causes; what we know and what we need to know', Population and Development Review 39, 2 (2013), 257-88 (257); J. Van Bavel, 'Subreplacement fertility in the West before the baby boom: past and current perspectives', Population Studies 64, 1 (2010), 1-18; D. Gauvreau, P. Sabourin, S. Vézina and B. Laplante, 'The mechanics of the baby boom: Unveiling the role of the epidemiologic transition', Population Studies 72, 3 (2018), 305-21; J. J. Sánchez-Barricarte, 'Measuring and explaining the baby boom in the developed world in the mid-twentieth century', Demographic Research. A peer-reviewed Open access Journal of Population Sciences 38, 40 (2018), 1189-240. 5 Van Bavel and Reher, 'The baby boom', 280-1. Also, Van Bavel, 'Subreplacement fertility', 1.

6 W. Kline, Bodies of knowledge. Sexuality, reproduction, and women's health in the second wave (Chicago and London, 2010).

7 Sánchez-Barricarte, 'Measuring and explaining', 1213.

8 Italy, Belgium, and France, see D. V. Glass, Population policies and movements in Europe (Oxford, 1940)

9 D. V. Glass, 'The effectiveness of abortion legislation in six countries', The Modern Law Review 2, 2 (1938), 97-125.

10 Glass, Population policies, 158-59.

11 The Norwegian Jews, see B. Bruland, Holocaust i Norge. Registrering, deportasjon og tilintetgjørelse (Oslo, 2017).

12 T. D. Østrem, 'Liv og helse', Tidsskrift for legeforeningen (1942), 482-513. Gogstad, Helse og hakekors, 101. 13 Ibid.

14 Ø. Giæver, 'Abortion and eugenics', Scandinavian Journal of History 30, 1 (2005), 21-44; P. Haave, Sterilisering av tatere 1934-1977. En historisk undersøkelse av lov og praksis (Oslo, 2000).

15 I. Bull, 'Norske legers holdning til spørsmålet om barnebegrensning', Historisk Tidsskrift 56, 49 (1977), 417; I. Blom, Barnebegrensning - synd eller sunn fornuft (Oslo, 1980); S. Sogner, 'Abortion, birth control, and contraception: fertility decline in Norway', The Journal of Interdisciplinary History 34, 2 (2003), 209-34.

16 Population statistics were produced immediately after the war, but later revised, see Historisk statistikk (Historical statistics) (1994), https://www.ssb.no/a/histstat/nos/nos_c188.pdf. See also Backer, Ekteskap.

17 The Nazi party leader Vidkun Quisling had, however, been the minister of defence from 1931 to 1932 , as a member of a Farmers Party minority government.

18 J. Debes, Sentraladministrasjonens historie, 1940-1945 (Oslo, 1978).

19 Ibid., 94-5.

20 Ø. Sørensen, Solkors og solidaritet. Høyreautoritær samfunnstenkning i Norge ca. 1930-1945 (Oslo, 1991).

21 M. Ohman Nielsen, Norvegr, Norges historie etter 1914 (Oslo, 2011).

22 Giæver, 'Abortion and eugenics', 28-9.

23 Historisk statistikk.

24 Backer, Ekteskap, 88.

25 Norwegian Government Yearbook 1942.

26 Riksarkivet (RA), Sosialdep, Helsedirektoratet, Befolkningskontoret, H6 (S), serie B - L 0001. Further references: RA/S-1288/B/L0001. Letter from S. Kvassnes to the county physician in Finnmark, 18 December 1941. 27 The 'Nordic race', see J. R. Kyllingstad, Measuring the master race. Physical anthropology in Norway 1890-1945 (Cambridge, 2014), 201-11. Open Book, www.jstor.org/stable/j.ctt157nd4.14 [accessed 1 May 
2020]. RA/S-1288/B/L0001. PM on unborn children in Norway signed by Sverre Kvassnes, 19 September 1941.

28 Illuminating in this respect is the description of abortion policies in occupied Poland and Czechoslovakia. H. Davis, J. Fleischacker and C. Hohn, 'Abortion and Eugenics in Nazi Germany', Population and Development Review 14, 1 (1988), 81-112 (101-5).

29 K. Olsen, Krigens barn. De norske krigsbarna og deres mødre (Oslo, 1998). 75-76.

30 From Kvassnes to the County medical officer in Finnmark, 18 December 1941; From Kvassnes to the County medical Officer in Honningsvåg, 5 January 1942. RA/S-1288/B/L0001.

31 Note from S. Saxlund to the Director General of Health (medisinaldirektør), 20 October 1943. RA/ S-1288/B/L0004. In regard of the Jews, the suggestion was somewhat outdated, as the Jews had been deported, had fled to Sweden, or were in hiding in Norway.

32 Olsen, De norske krigsbarna, 39.

33 S. Kvassnes, E. Rian and S. Saxlund, Slegt og individ (Oslo, 1944).

34 RA/S-1288/B/L0004. Letter from Th. Østrem to NS Organisation for foreign affairs (NS utenriksorganisasjon), 30 September 1943.

35 Ibid.

36 RA/S-1288/B/L0003. Letter signed by Th. Østrem to the Ministry of Church and Education, 30 April 1943.

37 B. Evjen and V. P. Lehtola, 'Mo birget soadis' (How to cope with war), Scandinavian Journal of History 45, 1 (2020), 24-47.

38 See note 34.

39 Evjen and Lehtola, 'Mo birget soadis', 30.

40 Population Investigation Committee. First Annual Report (1 January 1937-31 December 1937), 23943; Glass, 'The effectiveness of abortion', 116.

41 The book Befolkningsfrågan, by Alma and Gunnar Myrdal, was, for example, translated and adapted to Norwegian conditions by the social democrat and economist Aase Lionæs and Arne Skau. A. Myrdal and G. Myrdal, Krisen i befolkningsspørsmålet. Norsk utgave ved Aa. Lionæs and A. Skaug (Oslo, 1936).

42 A. Andresen and K. T. Elvbakken, 'Fødselskontroll, barnehelse og kvinners rettigheter og plikter', Tidsskrift for kjønnsforskning 1-2 (2018), 10-2. Similar ideas are to be found in many countries, see, for example, J. Rákosnik and R. Sustrová, 'Toward a population Revolution? The threat of extinction and family policy in Czechoslovakia 1930-1950s', Journal of Family History 43, 2 (2018), 177-93, 181-3.

43 S. Sogner, H. B. Randsborg and E. Fure, Fra stua full til tobarnskull (Oslo, 1984).

44 Sogner, 'Abortion, birth control and contraception', 224, 226.

45 Ibid., 211.

46 K. Fisher and S. Szreter, “They prefer withdrawal”: the choice of birth control in Britain, 1918-1950', Journal of Interdisciplinary History 34, 2 (2003), 263-91 (266-9); S. Szreter, R. A. Nye and F. W. van Poppel, 'Fertility and contraception during the demographic transition: qualitative and quantitative approaches', Journal of Interdisciplinary History 34, 2 (2003).

47 Sogner, 'Abortion, birth control and contraception', 226.

48 L. Kreyberg ed., Vår helse (Oslo, 1933); Populart tidsskrift for seksuell opplysning, published by Sosialistiske legers forening (The Association of Socialist Physicians).

49 Kreyberg ed., Vår helse, 442-50.

50 L. Lennerhed, Sex i folkhemmet. RFSUs tidliga historia (Uppsala, 2002), 36.

51 Bull, 'Norske legers holdning', 417.

52 C. Bruusgaard, 'Arven etter Katti Anker Møller', in K. Skjønsberg ed., Hvor var kvinnene? Elleve kvinner om årene 1945-1960 (Oslo, 1979), 13-41.

53 'Mødrehygienekontoret i Oslo 30 April 1924-30 April 1934', Bilag til Tidsskrift for den norske Lœegeforening 3, 10 (1934), 8.

54 'Mødrehygienekontoret i Oslo. Beretning for 1935 og1936', Bilag til Tidsskrift for den norske loegeforening 11 (1937), 4.

55 Measuring growth and development, giving information and advice on nutrition, especially promoting the use of mother's milk, was inspired by pediatrics and the public health-movement.

56 NOS IX 002. Sunnhetstilstanden og medisinalforholdene 1930 (Oslo 1933), 30.

57 NOS IX 070. Folkemengdens bevegelse 1921-1932 (Oslo 1935), 26.

58 Blom, Barnebegrensning, 190-5. 
59 The Archive for the labour movement in Oslo (Arbark) has all the editions of this journal (except 1922). It was not published during WWII.

60 The Regional State Archive, Troms $\varnothing$ (SATØ). Privatarkiv nr. 320, box 5. Protokoll for Mødrehygienekontoret 7 July 1935-24 February 1941. Board meeting 2 November 1935.

61 Glass, Population policies, 160.

62 Ibid., 218.

63 Blom, Barnebegrensning, 196-214; Andresen and Elvbakken, 'Fødselskontroll, barnehelse', 10-12.

64 A. Andresen and K. T. Elvbakken, 'Karl Evang og mødrehygienesaken. Om lojalitet, nøytralitet og faglig uavhengighet i helseforvaltningen (1938-1971)', Norsk statsvitenskapelig tidsskrift 2 (2017), 137-54.

65 The liberal party (Venstre) had, for example, been important in a legal reform that strengthened the position of unwed mothers and their children as early as 1915, and one of its leaders had collaborated with Katti Anker Møller, the initiator of the birth control clinics in Norway and an early spokeswoman for abortion on demand.

66 E.g. A. Skauge, Arbeiderkvinnen (The Labor Women's Journal) 3 (1936), 17-20.

67 Myrdal and Myrdal, Krisen i befolkningsspørsmålet.

68 Danielsen et al., Norway, a History, from the Vikings to our own times (Oslo, 1988) 347.

69 Blom, Barnebegrensning, 218-22, 231-4; Andresen and Elvbakken, 'Om lojalitet', 137-54.

70 Morgenavisen 9 May 1932.

71 Bull, 'Norske legers holdning', 292-310.

72 G. Evang, 'Vi må få et nett av mødrehygienekontor utover hele landet. Skandinavias første mødrehygienekontor blev til i Oslo', Arbeiderkvinnen (The Labor Women's Journal) 5, 4-5.

73 Members of the Socialist Medical Association.

74 Sogner, 'Abortion, birth control and contraception', 292-310.

75 Straffelovkomiteen av 1934, Innstilling $n r .1$ (Oslo, 1935).

76 Straffelovkomiteen, Innstilling $n r .1$; Sogner, 'Abortion, birth control and contraception', 230.

77 RA/JD/De/L0039/ S-3212 (Ministry of Justice, Legislation Department) Straffelovens revisjon: 8 Abortus provocatus, 1935, Letters from app. 140 local Labour Women's Organization departments.

78 Proceedings from the Storting, O.tid.273, (3.3.1939). Min. of Justice RA/JD/De/L0039/ S-3212 (jnr. 403/39) A private proposal for abortion legislation sent from the parliament to the government and thereafter to the Ministry of Justice.

79 The numbers of legal abortions, Ot.pr.15, 1959, attachment, 11, 73. Innstilling fra straffelovrådet.

80 The Oslo birth control clinic. Report to the board on the activity in 1936.AAB/ARK 1532/D/L0002/ 0001.

81 Annual Report 1937, National Organisation for Birth Control Clinics (Landsforeningen for mødrehygiene) AAB/ARK 1532/D/L0002/0001

82 SATØ, Privatarkiv nr. 320, box 5. Protokoll for Mødrehygienekontoret 7 July 1934-24 February 1941. Board meeting 23 February 1938.

83 SATØ, Privatarkiv nr. 320, box 5. Protokoll for Mødrehygienekontoret 7 July 1934-24 February 1941. Board meeting 24 February 1941.

$84 \mathrm{H}$. Danielsen, Dei moderne kvinnene i Odda. Ein studie av mødrehygiene og barneavgrensing i mellomkrigstida (Tyssedal, 2000).

85 N. Hoel, 'Erfaringer fra de fire første månedene med drift ved Skiensfjordens Mødrehygienekontor', Tidsskrift for den norske Logeforening 5 (1932), 304-16.

86 Evang, Arbeiderkvinnen, 14.

87 Bergen byarkiv (BBY). A 1648, Ha: 3, Bergen mødrehygienekontor 1934-1973. Beretning for året 1939.

88 BBY. Bergen helseråd, helseavdelingen, 2309, 6: 37. Letter from Bergen mødrehygienekontor to Bergen Helseråd, 20 March 1934.

89 The Tromsø office rented a post box in 1939 to use this address in its advertisements, probably for reasons of discretion. SATØ, Privatarkiv nr. 320, box 5. Protokoll for Mødrehygienekontoret 7 July 1934-24 February 1941. Board meeting 19 January 1939.

90 Grossmann, Reforming sex, 136-41.

91 Aftenposten 29 April 1941, message from NTB, Norwegian Telegram Bureau.

92 B. Skar, 'Morstanken og folket vårt' (Motherhood and our people) (radio speech) printed in 'Vår ungdom og vår fremtid' (Our youth and our future) (Oslo, 1941). 
93 RA, S, serie D, Stenging og likvidering av mødrehygienekontor (1941-1945). Further references: RA/ S-1288/D/L001/0001. Report to the Chief of Police in Trondheim from police officer Sørlie, 25 April 1942. Also letter to The Population Office from Søren Lydersen, 20 June 1942.

$94 \mathrm{RA} / \mathrm{S}-1288 / \mathrm{D} / \mathrm{L} 001 / 0001$. Letter to the Oslo police authorities from Borghild Skar, 22 October 1941. 95 RA/S-1288/D/L001/0001. Report on the activity at Trøndelag Mødrehygienekontor, by Søren Lydersen, received by the Population Office 29 March 1943.

96 Mødrehygienekontoret i Oslo, Beretning for 1935 og 1936, 10.

97 RA/S-1288/B/L0003. Report on the work of the Population Office, 25 September 1941-4 February 1943. $98 \mathrm{RA} / \mathrm{S}-1288 / \mathrm{B} / \mathrm{L} 0001$. Letter from the Population Office to the director general of health, 6 July 1941. See also RA/S-1288/B/L0003. Letter from S. Saxlund to the district medical officer in Naustdal, 10 February 1943.

99 RA/S-1288/B/L0001. Letter from Th. Østrem to NSK, 17 April 1942.

100 RA/S-1288/B/L0001. Letter from S. Kvassnes to fylkeslege H. Borgersen, Honningsvåg, 5 January 1942.

101 RA/S-1288/B/L0001. Letter from Borghild Skar to the mayor, Odda, 15 December 1941, and from E. Kvassnes to NSK 3 January 1942.

$102 \mathrm{RA} / \mathrm{S}-1288 / \mathrm{B} / \mathrm{L} 0001$. Letter from S. Kvassnes to the Ministry of Interior, 2 February 1942.

103 Gogstad, Helse og hakekors, 129.

104 RA/S-1288/B/L0001. Letter from S. Kvassnes to Welander, Statistisk avd., Oslo, 16 December 1941.

$105 \mathrm{RA} / \mathrm{S}-1288 / \mathrm{B} / \mathrm{L} 0001$. Letter from S. Kvassnes to the leadership of NSK, 19 February 1942.

106 Gogstad, Helse og hakekors, 131.

107 Glass, Population policies, 99.

108 Cf. also L. King, "France needs children": Pronatalism, Nationalism and Women's Equity'. The Sociological Quarterly 39, 1 (1998), 33-51 (37-9).

109 Glass, Population policies, 294, 298.

110 Sørensen, Solkors og solidaritet, 135-7. SJEKK

111 Debes, Sentraladministrasjonens, 148.

112 RA/S-1288/B/L0003. PM from Th. Østrem dated 1 June 1943.

113 Forordning nr. 64, 27.09.1941. Norsk Lovtiend 1941, 937. RA/S-1288/B/L0001. Meddelelse til landets leger 16 December 1941. From Hagelin, Ministry of Interior. See also RA/S-1288/B/L0004, Letter from Th. Østrem, Population Office, 13 October 1943.

114 Forordning nr. 64, 27. 09.1941.

115 H. David, J. Fleischhacker and C. Hohn, 'Abortion and eugenics in Nazi Germany', Population and Development Review 14, 1 (1988), 96; Glass, Population policies, 216.

116 This is seen in a PM from the Population Office signed by S. Kvassnes, dated 19 June 1942. RA/ S-1277/B/L0001.

117 RA/S-1288/B/L0004. Letter from Th. Østrem, 20 October 1943.

118 RA/S-1288/B/L0004. Letter from Haneide to Apoteket Nordstjernen, 12 July 1943.

$119 \mathrm{RA} / \mathrm{S}-1288 / \mathrm{B} / \mathrm{L} 0004$. Notification to the country's physicians from Th. Østrem, 13 October 1943.

120 RA/S-1288/B/L0001. Comments from the Population Office, 22 May 1942.

121 See W. Kline, Building a better race. Gender, sexuality, and eugenics from the turn of the Century to the Baby Boom (California, 2001) 32-60; A. Basford and P. Levine eds., The Oxford handbook of the history of eugenics (UK, 2010).

122 Gogstad, Helse og hakekors, 196-201. P. Haave, Sterilisering av tatere 1934-1977. En historisk undersøkelse av lov og praksis (Oslo, 2000), 115-35.

123 L. Kreyberg ed., Vår Helse. Populart norsk legeverk (Oslo, 1931), 448.

124 Gogstad, Helse og hakekors, 203.

125 Haave, Sterilisering av tatere, 167-70.

126 P. Haave, Sterilisering på medisinsk grunnlag og sammenhengen mellom eugenikk og humangenetikk, et for-prosjekt. Med vedlegg om Sentralkartoteket for åndssvake og arvelighetsregisteret ved Universitetet $i$ Oslo (Oslo, 2000), 34.

127 Dr. K. Skajaa, Appendix 2 in the report from the abortion law committee, 1956: Innstilling fra Straffelovrådet om adgangen til å avbryte svangerskap. Ot.prp. 15 (1959) Om lov om avbrytelse av svangerskap.

128 RA/JRDJ S-3212 Justisdepartementet Lovavdelingen, RA/S-3212D/De- L0039-L0040, Straffelovens revisjon: 8, Abortus provokatus. Letter from the medical director, Th Østrem, to the Ministry of the 
Interior 22 March 1941, followed by letter from this ministry to the Ministry of Justice, 26 March 1941 (j.nr.478-1941).

129 Parliament papers, Document 8, 1939, number 2: Forslag til lov om forandringer i straffelovens $\$ 245$ og forslag til lov om rett til å avbryte svangerskap i visse tilfelle, 28 February 1939.

130 Giæver, 'Abortion and Eugenics', 28-9. RA/JRDJ S-3212 Justisdepartementet Lovavdelingen De L0037- L0041, Straffelovens revisjon: 8, Abortus provokatus.

131 David, Fleischhacker and Hohn, 'Abortions and eugenics', 96.

132 Grossmann, Reforming sex, 152.

133 Dr. Kristjar Skajaa in Ot.prp. 15 (1959) Om lov om adgang til å avbryte svangerskap, 68.

134 RA/S-1288/B/L0004. PM signed S. Kvassnes, 26 November 1943.

135 Ibid.

136 RA/S-1288/B/L0003. Letter from Th. Østrem to the Ministry of Justice, 26 May 1943.

137 RA/S-1288/B/L0004. Letter from S. Saxlund to the Attorney General, 31 August 1943.

138 NOS X. 172. Folkemengdens bevegelse 1942-1945 og sammendragstabeller 1941-1945 (Statistisk sentralbyrå, Oslo, 1949), $10^{*}$.

139 NOS X. 172. Folkemengdens bevegelse.

140 Olsen, De norske krigsbarna, 81-115.

141 A. Andresen, Hender små. Bortsetting av barn i Norge 1900-1950 (Bergen, 2006), 196.

142 1935: 14.3; 1936: 14.55; 1937: 15,01: 1938: 14.44; 1939: 15.77; 1940: 16,13; 1941: 15.31; 1942: 17.79; 1943: 18.89; 1944: 20.34; 1945: 20.00. Historisk statistikk. Tabell 3.13, 79.

143 Historisk statistikk.

144 Historisk statistikk, 89.

145 Van Bavel and Reher, 'The baby boom', 279.

146 Backer, Ekteskap, 27.

147 Ibid., 143, 145.

148 Ibid., 140.

149 Ibid., 89. A similar war-time increase is found also elsewhere, see Van Bavel and Reher, 'The baby boom', 260-62. Rákosnik and Sustrova explains the rise in a similar way as Backer. They explicitly hold pro-population interventions to have of no effect. Rákosnik and Sustrová, 'Toward a Population Revolution', Journal of Family History 2 (2018), 181.

150 Backer, Ekteskap, 88-9.

151 G. Hjeltnes, Hverdagsliv i krig. Norge 1940-1945 (Oslo, 1987), 97-121.

152 Ibid., 58-9.

153 https://www.ssb.no/a/histstat/aarbok/ht-0901-bnp.html.; Danielsen et al., Norway, A history, 326-33.

154 Ibid., 343-4.

155 E. Bull, Klassekamp og fellesskap 1920-1945. Norges historie bd. 13 (Oslo, 1988), 292-313; Danielsen et al., 343 .

156 S. Hansen and T. Skoglund, Utviklingen i sysselsetting og lønn etter (1930), https://www.ssb.no/a/publikasjoner/pdf/oa_200806/skoglund.pdf

157 For example, Backer, Ekteskap, 85; Van Bavel, 'Subreplacement fertility', 5.

158 Ohman Nielsen, Norvegr, 107.

159 Blom, Barnebegrensning, 218-22, 231-4. Andresen and Elvbakken, 'Om lojalitet', 137-54.

\section{French Abstract}

\section{Guerre et paix. Contrôle des naissances et politiques démographiques en Norvège} (1930-1945)

Dans les années 1930, la Norvège mena une politique relativement libérale en matière d'accès aux contraceptifs et le nombre d'avortements pratiqués en toute légalité y alla croissant en cette période de paix. Mais avec la période d'occupation intervenue en 1940, les interruptions de grossesse furent drastiquement freinées. Non seulement le nouveau régime mis en place obéit à l'idéologie nazie mais il redouta fort un menaçant déclin 
de la population. A titre de comparaison, les auteurs évoquent les politiques démographiques mises en œuvre dans d'autres pays d'Europe occidentale à la même époque. Pour la Norvège, les mesures de politique démographique prises sous l'occupation sont étudiées et comparées à celles des années 1930. La question posée est de savoir si tous les groupes furent traités de la même façon et dans quelle mesure les politiques nouvelles contribuèrent à relever les taux de natalité en Norvège occupée.

\section{German Abstract}

Im Frieden und im Krieg: Geburtenkontrolle und Bevölkerungspolitik in Norwegen (1930-1945)

Während in Norwegen in den 1930er Jahren im Hinblick auf den Zugang zu Empfängnisverhütungsmitteln eine relativ liberale Politik herrschte und eine steigende Zahl von legalen Schwangerschaftsabbrüchen durchgeführt wurden, verfolgte das nach der Besetzung im Jahre 1940 installierte Regime einen Eindämmungskurs, der nicht nur durch die Ideologie der Nazis befeuert wurde, sondern auch durch einen aus Sicht der Regierung höchst bedrohlichen Bevölkerungsrückgang. Unter Bezugnahme auf die Bevölkerungspolitik in anderen westeuropäischen Ländern vergleicht dieser Beitrag die norwegische Bevölkerungspolitik während der Besetzung mit derjenigen in den 1930er Jahren, erörtert die Frage, ob die Politik gegenüber allen Gruppen gleich war, und untersucht, inwiefern die neue Bevölkerungspolitik zu steigenden Geburtenraten im besetzen Norwegen beitrug. 